\title{
A hermeneutical reflection on the resurrection of Jesus Christ in question and answer 45 of the Heidelberg Catechism
}

\begin{tabular}{|c|c|}
\hline \multicolumn{2}{|c|}{$\begin{array}{l}\text { Author: } \\
\text { Kobus Labuschagne }{ }^{1}\end{array}$} \\
\hline \multicolumn{2}{|c|}{$\begin{array}{l}\text { History and Church Polity, } \\
\text { University of Pretoria, } \\
\text { South Africa }\end{array}$} \\
\hline \multicolumn{2}{|c|}{$\begin{array}{l}\text { Correspondence to: } \\
\text { Kobus Labuschagne }\end{array}$} \\
\hline \multicolumn{2}{|c|}{$\begin{array}{l}\text { Email: } \\
\text { kobus.labuschagne@ } \\
\text { telkomsa.net }\end{array}$} \\
\hline \multicolumn{2}{|c|}{$\begin{array}{l}\text { Postal address: } \\
\text { Private Bag X20, Hatfield } \\
0028 \text {, South Africa }\end{array}$} \\
\hline \multicolumn{2}{|c|}{$\begin{array}{l}\text { Received: } 15 \text { Mar. } 2013 \\
\text { Accepted: } 28 \text { June } 2013 \\
\text { Published: } 03 \text { Oct. } 2013\end{array}$} \\
\hline \multicolumn{2}{|c|}{$\begin{array}{l}\text { How to cite this article: } \\
\text { Labuschagne, K., 2013, 'A } \\
\text { hermeneutical reflection } \\
\text { on the resurrection of } \\
\text { Jesus Christ in question and } \\
\text { answer } 45 \text { of the Heidelberg } \\
\text { Catechism', In die Skriflig/In } \\
\text { Luce Verbi } 47(2), \text { Art. \#709, } \\
10 \text { pages. http://dx.doi. } \\
\text { org/10.4102/ids.v47i2.709 }\end{array}$} \\
\hline \multicolumn{2}{|c|}{$\begin{array}{l}\text { Note: } \\
\text { Dr Kobus (J.P.) Labuschagn } \\
\text { is participating as research } \\
\text { fellow of Prof. Dr Graham } \\
\text { Duncan, Department of } \\
\text { Church History and Church } \\
\text { Polity, Faculty of Theology, } \\
\text { University of Pretoria, } \\
\text { South Africa. }\end{array}$} \\
\hline \multicolumn{2}{|c|}{$\begin{array}{l}\text { (C) 2013. The Authors. } \\
\text { Licensee: AOSIS } \\
\text { OpenJournals. This work } \\
\text { is licensed under the } \\
\text { Creative Commons } \\
\text { Attribution License. }\end{array}$} \\
\hline \multicolumn{2}{|l|}{ Read online: } \\
\hline 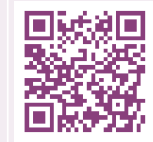 & $\begin{array}{l}\text { Scan this QR } \\
\text { code with your } \\
\text { smart phone or } \\
\text { mobile device } \\
\text { to read online. }\end{array}$ \\
\hline
\end{tabular}

This article is an attempt to elaborate hermeneutically on the different historical contexts, related the one to the other and to the centre point of the resurrection of Jesus Christ, in question and answer 45 of the Heidelberg Catechism. The aim is not only to find the true meaning that the Heidelberg Catechism intends to convey in the mentioned question and answer, but also to explain the underlying hermeneutical thinking as well as to bring to the surface and explain alternative assumptions that ordinary church-going Christians experience as the unusual outcome of an unknown and different kind of approach. Different hermeneutical processes lead to different outcomes of understanding - sometimes worlds apart.

'n Hermeneutiese besinning oor die opstanding van Jesus Christus in vraag en antwoord 45 van die Heidelbergse Kategismus. Vanuit die sentrale punt van die opstanding van Jesus Christus in vraag en antwoord 45 van die Heidelbergse Kategismus, wil hierdie artikel in 'n hermeneutiese besinning oor die verskillende verbandhoudende historiese kontekste uitbrei. Die doel is nie slegs om die ware betekenis te vind van wat die Heidelbergse Kategismus in genoemde vraag en antwoord poog om weer te gee nie, maar ook om die onderliggende hermeneutiese denke te verduidelik en alternatiewe aannames, wat gewone Christenkerkgangers as 'n vreemde en verskillende benaderings ervaar, na die oppervlakte te bring en te verduidelik. Verskillende hermeneutiese prosesse lei tot verskillende uitkomste van verstaan - soms wêrelde van mekaar verwyderd.

\section{Introduction}

Arguably, for a considerable number of church-going Christians there are tendencies within and surrounding the church nowadays that, to them, reflect a negative kind of theology and that they feel that it is more likely to harm the church than unite people and build the church in the service of the Lord. In its search for answers within man's reach, pointing hopefully at least in the direction of truth and reality, this article has been conducted in close conjunction with specific hermeneutical processes of understanding. Different hermeneutical processes lead to different outcomes of understanding - sometimes worlds apart. In our search for answers, history presents us with ample and indispensable evidence that ought to be taken into account.

Different theological approaches seem to be an inevitable part of reality (cf. 1 Cor 1:22-24 - two groups want man to be in easy control, and the third accept God's control of revealing himself). Whilst theological integrity needs to be required and respected, it is certainly worthwhile to take Karl Barth's (1972) comment into consideration:

The theology of any period must be strong and free enough to give a calm, attentive and open hearing not only to the voices of the Church Fathers, not only to favourite voices, not only to the voices of the classical past, but to all the voices of the past [...] It may always be that we have especial need of quite unsuspected (and among these, of quite unwelcome) voices in one sense or another. (p. 17)

In 2013 we have the privilege of celebrating the major contribution of the Heidelberg Catechism (HC) in the 450 years since its first publication in 1563. The HC is widely accepted as part of the reformed confessional basis, and has proven itself to remain as a significant force in the intellectual development of Protestantism. Kevin L. DeYoung (2010:16) claims: 'Besides the Bible, John Bunyan's Pilgrim's Progress, and Thomas à Kempis' Imitation of Christ, the HC is the most widely circulated book in the world.'

The HC was in some ways the result of the fatherly initiative of Frederick III, 'who commissioned the HC, directed its production, secured its approval by a Heidelberg synod in January 1563, and defended it before the imperial diet three years later' (Bierma 2005a:52). What Frederick had in mind, was the goal of uniting Protestant groups in the Palatinate (Bierma ibid:49). The consensus 
amongst researchers today is that, although the $\mathrm{HC}$ was to some extent a team effort of the leading theologians and church officials of the Palatinate, Zacharias Ursinus (1534-1583) was in all likelihood the primary author and final editor of the $\mathrm{HC}$, and he became its chief expositor and apologist since its publication in 1563 (cf. Bierma ibid:71-74). The intent of the $\mathrm{HC}$ was indeed from the beginning to overcome the divisions amongst the Protestant groups (Bierma 2005b):

The focus is nearly always on common theological ground among the followers of Melanchthon, Calvin, and Bullinger. In this limited respect, at least, we may speak of the ecumenical spirit of the HC. (p. 102)

This article is an attempt to elaborate hermeneutically on the contribution of the different historical contexts (related to the centre point of the resurrection of Jesus Christ) towards a better understanding of the true meaning of question and answer 45 of the HC. The aim is, however, not only to find the real meaning of what the $\mathrm{HC}$ says in the mentioned question and answer, and to explain its underlying hermeneutical thinking, but also to bring alternative views to the surface and to explain those assumptions, which ordinary church-going Christians experience as, to them, the unusual outcome of an unknown and different kind of approach.

Question 45 of the HC reads: 'What benefit do we receive from "the resurrection" of Christ?', with the answer reading (Barth 1964):

First, by his resurrection he has overcome death that he might make us share in the righteousness which he has obtained for us through his death. Second, we too are now raised by his power to a new life. Third, the resurrection of Christ is a sure pledge to us of our blessed resurrection. (p. 73)

\section{Methodological consideration and accountability}

With words we express meaning and understanding. Words are, however, always related to a background or context. Then there is also the ripple effect created by multiple interdependent contexts to contend with. Context operates through both word and event. Context is the originating factor, resulting in our words through which we give meaning. Context cannot be downplayed, nor underestimated. Jacques Derrida's sentence is well-known: '[T]here is nothing but context, and therefore: there is no outside-the-text' (cf. Maley 2011:1). By taking the various related contexts into consideration, the scope of our existing understanding widens. Referring to the 'contextual action' that leads to a change of meaning in a word, Paul Ricoeur (2009:166) says that a "word is always the bearer of the "emergent meaning" which specific contexts confer upon it'. Specific contexts, which emerge through both words and real events, play a decisive role in the content we express in words. And through content, we communicate meaning and understanding. Relation to contexts implies that the interpretation of 'metaphors is illuminated by the interpretation of the text as a whole and by the clarification of the kind of world which the work projects' (Ricoeur ibid:180-181). Therefore, fragmentation of the text and losing sight of various related contexts lead to evidence and meaning being destroyed. Not losing sight of the backgrounds that metaphors have in real events, Jürgen Moltmann (2000:166) adds that 'a metaphor begins to illuminate only if not everything is metaphorical'.

Elaborating on context, Martin Kähler (1835-1912) became aware of the effect that the Lord Jesus had on people, especially the apostles and their associates. Kähler worked backwards - from effects to the causes of the effects, the context, namely the Christ-event and the person of the Lord Jesus (cf. Kähler 1964:62-71). In his introduction to Kähler's book, The socalled historical Jesus and the historic, biblical Christ, Carl E. Braaten notes that it was important to Kähler to break through Schleiermacher's 'monistic immanentalism' and to 'escape the limitations of subjectivism', to recover 'historical revelation', to object when 'a measure of productivity is conceded to the religious consciousness as such', and to object to 'a faith which begins by relying upon itself, upon the fact of its own existence', which would mean the loss of the 'immediate relation to the historic, biblical Christ' (Kähler ibid:13). Working backwards from the effect to the cause, Kähler (ibid) refers to:

[T] he Jesus whom the eyes of faith behold at every step he takes and through every syllable he utters - the Jesus whose image we impress upon our minds because we both would and do commune with him, our risen, living Lord. The person of our living Savior, the person of the Word incarnate, of God revealed, gazes upon us from the features of that image which has deeply impressed itself on the memory of his followers [...] which was finally disclosed and perfected through the illumination of his Spirit. (pp. 66-67)

Gadamer identifies effect with understanding in his exposition of how historically effected consciousness (wirkungsgeschichtliches Bewußtsein) operates: 'Understanding proves to be a kind of effect and knows itself as such' (Gadamer 2006:336). He (Gadamer ibid) also states:

When a naïve faith in scientific method denies the existence of effective history, there can be an actual deformation of knowledge [...] Consciousness of being affected by history (wirkungsgeschichtliches Bewußtsein) is primarily consciousness of the hermeneutical situation. (pp. 300-301)

Furthermore, what needs to take place when studying texts and related contexts, is what Gadamer (2006) calls a 'fusion of horizons':

$[U]$ nderstanding is certainly not concerned with $[\ldots]$ reconstructing the way the text came into being. Rather, one intends to understand the text itself. But this means that the interpreter's own thoughts too have gone into re-awakening the text's meaning. In this the interpreter's own horizon is decisive, yet not as a personal standpoint that he maintains or enforces, but more as an opinion and a possibility that one brings into play and puts at risk, and that helps one truly to make one's own what the text says. I have described this above as a 'fusion of horizons'. (p. 390)

There should be guarded against the reflection of the researcher obscuring the text. Reflection is then merely the projection of the researcher's contemporary predetermined convictions, neutralising the influence of the text (or the past). Instead, a consciousness is required in which history, as object of the research, is allowed to approach the researcher and 
express itself (cf. Gadamer 2006:336-341). Richard E. Palmer (1969) adds:

The idea of freeing understanding and interpretation from the prejudices of the prevailing opinion of the time is quite common to us. It would be ridiculous, we commonly say, to judge the achievements of a past age by the standards of today. The objective of historical knowledge, then, can only be fulfilled through freedom from personal ideas and values on a subject and a perfectly 'open mind' to the world of ideas and values of the past. (p. 181)

Yet, in referring to the so-called New Hermeneutic, William W. Klein, Craig L. Blomberg and Robert L. Hubbard (1993) observe:

Instead of employing a methodology or process for determining the meaning of texts (i.e., what they historically intended to communicate) [... ] They studied the text through the lenses of today, rather than seeking to understand life today through the interpretation of the text. (p. 105)

We cannot change what happened in the past; we cannot invent history (cf. Young 2007:xiv).

This article is committed to the search for meaning and understanding by disclosing specific historical contexts imperative to understanding the HC: the contexts of the Reformation as well as the New Testament (NT) and Early Church. The destiny of the Early Church was entwined with the period of the NT, with both their contexts becoming very important in the understanding of the other.

\section{The hermeneutical point of departure}

There are theologians who explain question and answer 45 of the $\mathrm{HC}$, and the Easter message as such, in a purely spiritual way. In such cases, we are presented with only the challenge and idea of a new and better way of living. Metaphorically, a resurrection to a new life of faith is suggested. For this kind of faith there is accordingly no need for a background in a real event of a real and bodily resurrection of the Lord Jesus Christ. Rudolf Bultmann (1884-1976) refrains from referring to 'tangible demonstrations' and cannot see in the Easter stories 'more than they are able to be: signs and pictures of the Easter faith' (Bultmann 1993:57). Bultmann (1989) stresses the human consciousness as man's last resort:

$[W]$ e can talk about God's act only if we at the same time talk about our own existence, so that God's act cannot be established outside our own being affected by it. (p. 113)

He (Bultmann 1989) furthermore states that:

[...] in the existential openness of my person [...] I already understand what friendship, love, and fidelity are, [...] because my existence has need of them [... ] So, too, I can understand what God's grace means. (p. 105)

The starting point and determining factor is human existence with its needs and, exclusively, the reasoning of the human mind.

In commenting on question and answer 45, Eberhard Busch (2010) emphatically states that if the cross and resurrection of
Christ was only an idea, we do not need a real Christ and we are then entirely on our own, stepping into emptiness:

The truth of Easter [...] is not a general truth that holds just as well independently of Christ [...] at most a parable. As soon as his exaltation is only an example of an idea [...] it is a matter that functions completely without him. Then in truth he is no longer to be found, and so the meaning of his exaltation is also no longer to be found by us. We humans then remain by ourselves and in a world that according to the Easter message 'has passed away' (2 Cor 5:17). God's stepping in for us on the cross then points into emptiness [...] Then it would be as though 'Christ has not been raised'. (cf. 1 Cor 15:14; p. 196)

Karl Barth (1886-1968), in his response to question and answer 45 , also decisively rejects a purely spiritualised understanding of the resurrection. The presupposition of the human mind's inherent understanding of human existence and faith, without the determining impact and driving force of an external reality and event, is unacceptable to Barth (1964):

The 'resurrection of Jesus Christ' means the resurrection of this one person distinguished from all others, and thus an event in time and space just like the event of Golgotha. If it does not mean that, this event is reduced to a new determination of human existence, to the awakening of faith in the first disciples. Then there is no Christ for us and over us to substantiate the existence of Christ in us. Then the Easter message as such is subverted and nullified. (pp. 75-76)

On the basis of his important distinction (cf. Barth 1955:160) between Historie [history as scientific research] and Geschichte [real events as experienced and witnessed by ordinary people], Barth (1964) continues with his explanation:

[T] he Easter message does in fact not have the character of Historie [...] The historian will speak here of saga and legend. If Bultmann wanted only to say that we are concerned here with history (not myth!) in the form of saga and legend, there could be no objection to him [...] But it is not possible to deny the really historical character of the account because it has this form $[\ldots]$ The Bible contains innumerable sagas and legends. But it would be false to conclude from this fact that they are not the expression of real happenings. In no case does the Bible intend to present timeless truths or myths. And so also in this case, it intends to be genuine history (Geschichte), but history in a form inaccessible to Historie. (p. 76)

Significantly, to Barth the real and only order of the Easter faith is as follows: Easter event, Easter message, and then Easter faith. He does not accept Bultmann's subjective point of departure: first Easter faith, and then Easter message, and no preceding event (Barth 1964:76). Barth (ibid) elaborates:

Whoever begins with the Easter faith in order to make it the content of the Easter message and finally indulgently to let the Easter event fall away - his talk on this subject is boring and certainly not legitimate. (p. 76)

In Barth's thinking God can never be portrayed as the immanent (inherent) possibility of human reasoning.

Clearly, the crux of the matter is the two different points of departure in the hermeneutical process. However, hermeneutically the goal remains to understand. That means that you either start with man's utter lack of capability to reach God and then have to respond to God's self-revelation in Jesus 
Christ, like Luther, Barth, Moltmann and Pannenberg, or you have to fall back upon the conviction of the human mind as your last and only resort like Bultmann and Schleiermacher, for instance, who went back to Immanuel Kant's philosophy of the autonomous human mind and practical reason. For Immanuel Kant (1724-1804) the spiritual world (of religion and faith, following from the basis of morality) is inaccessible to historical and scientific research. The autonomous human mind as sole source of the moral law, without accepting any heteronomy, lets subjectivity reign in the spiritual world. No outside power is needed for human decisions - no real and historical Jesus is needed. With that Kant separates literal understanding (in his theoretical reason, referring to objective scientific research) from spiritual and symbolic understanding (in his practical reason).

Kant works with a concept of a 'Supreme Being' without 'limitations or admixture of empirical elements'. He indeed works with an understanding of two worlds (Kant 1974:371). This concept's 'validity' (Kant ibid:372), however, is rooted in morality:

Now I maintain that all attempts of reason to establish a theology by the aid of speculation alone are fruitless, that the principles of reason as applied to nature do not conduct us to any theological truths, and, consequently, that a rational theology can have no existence, unless it is founded upon the laws of morality. (p. 370)

The question of which hermeneutical path was followed by the Heidelberg Catechism in question and answer 45 remains to be answered.

\section{The explanation of question and answer $\mathbf{4 5}$ in the commentary of Zacharias Ursinus - The hermeneutical point of departure and the bodily resurrection The similarity of a broader reformation context}

Two things that stand out in the Reformation's doctrinal documentation:

1. The Easter faith has its background in the real event of Christ's resurrection.

2. The resurrection is understood as a bodily resurrection, meaning man in unity of body and spirit.

In his study of the latest research on the two catechisms written by Ursinus, the Catechesis minor [Smaller Catechism - SC], and Catechesis maior [Larger Catechism - LC], Lyle D. Bierma states that 'it is safe to conclude that the SC, a lay catechism that did serve as a draft for the HC, was penned sometime before the LC' (Bierma 2005c:138). The SC was drawn up in late 1561 or early 1562, and the LC in late 1562. The LC was intended for university students (Bierma ibid:138). Inevitably, both the SC and LC formed a context for the development of the HC.

Christ is depicted as truly human and true God in question and answer 24 and 25 of the SC (Ursinus 2005a:145) and in question and answer 65 of the LC (Ursinus 2005b:174). In the
$\mathrm{HC}$, in his commentary on question and answer 36, Ursinus offers a detailed explanation of the full humanity and the full divinity in the one person of Christ, and then in its relation to man's redemption (Ursinus 2012:207-211). Question and answer 33 of the SC addresses the bodily resurrection of Christ, stating (Ursinus 2005a):

That by his divine power he called his body back to life and adorned it with eternal glory, so that the human Jesus Christ, at the appointed time, might raise from the dead also me and all who believe in him. (p. 146)

Question and answer 90 to 92 of the LC deals with the meaning of the bodily resurrection of Christ, and inter alia stating firmly and clearly: 'That the divinity of Christ by its own almighty power called back to life his body [...] and adorned it with immortality and heavenly glory'. For those who believe in Christ, this means 'death has been overcome by Christ' and that 'they have already received from him the beginnings of righteousness and eternal life' (Ursinus 2005b:179).

Shifting the focus to further contexts found in the catechisms of Luther and Calvin as well as the Augsburg Confession, yields the same results. In the second article of Luther's Small Catechism (May 1529), the Christology is explained by way of its relation to Christ being true God and true man, and in the third article the resurrection of the body and the life everlasting is expounded in the details of sanctification (Luther 2005a:355-356). In the third article of his Large Catechism (April 1529), Luther gives an exposition of the meaning of Christ's 'suffering, death, resurrection' within the sphere of Ecclesiology and Pneumatology, and how it affects the 'forgiveness of sins, the resurrection of the body, and the life everlasting' (Luther 2005b:428-432). The Augsburg Confession (1530) confesses in the third article: 'There is one Christ, true God and true man' who 'truly rose again on the third day' (Augsburg Confession 2005:58). The significance of bodily resurrection is more than clear in, for instance question and answer 80 and 109 of Calvin's Catechism (1545), with answer 109 going into some detail of the future human body (Calvyn 1981:18, 22).

\section{The Heidelberg Catechism}

As primary author, final editor, chief expositor and apologist of the $\mathrm{HC}$, the explanations of Zacharias Ursinus (1534-1583) in his Commentary on the Heidelberg Catechism is obviously crucial and decisive. Hermeneutically, the context of the indispensable contribution of Ursinus becomes overwhelmingly important. In his interpretation of question and answer 45 of the HC, Ursinus gives an exposition of the meaning of the 'resurrection of Christ' in its relation to us 'too [...] now raised by his power to a new life'. But his exposition is explicitly not a purely subjective portrayal of a new life, an idea, without any connection to real events. It is really the opposite. Hermeneutically, his point of departure is truly a real event - the bodily resurrection of our Lord, Jesus Christ, which is similar to the understanding of the NT and the Early Church (Ursinus 2012):

That Christ, however, did rise from the dead is proven by the testimony of angels, women, evangelists, apostles, and other 
saints, who saw him, felt him, and conversed with him after his resurrection. (p. 233)

Hermeneutically, the sequence followed by Ursinus is decisive: first the real event of God's revelation in Christ, then afterwards the message and faith. Thus, the point of departure is definitely not the contemplations of the subjective and autonomous human mind.

Ursinus' explanation of the resurrection necessarily becomes more clear when understood in light of his exposition of question and answer 25, which addresses the concept of the holy Trinity, question and answer 33, concerning the divinity of Christ, and question and answer 35 and 36, pertaining to the two natures of the divinity and the humanity in the one person of Christ (Ursinus 2012:119-139, 181-202, 205-211).

According to Ursinus (2012), and similar to the testimony of the NT and the Early Church, the resurrection of Christ was a bodily resurrection (Lk 24:39) within the unity of body and spirit:

Yea, had not the flesh of Christ risen, ours could not rise [...] He rose by his own power, that is [...] quickened his dead body, reunited it with his soul, and restored to himself a blessed, heavenly, and glorious life, and that by his own divine virtue and power [...] The Father raised the Son through the Son himself, not as through an instrument, but as through another person of the same essence with himself, and of infinite power [...] he himself raised himself by his Spirit (p.234)

[A]nd that by his Father's, as well as by his own peculiar strength and power, we mean, the power not of his humanity, but of his Divinity. (p. 233)

He rose the same person, the same Jesus Christ, very God and very man, which had died; he rose according to the same nature in which he had suffered, which was his human nature, his true human nature, the very same which it was in essence and properties, not deified, but glorified, having laid aside all the infirmities to which it was subject [...] The very same body, therefore, which had fallen a victim to death rose again; and it is this which affords us such great comfort. (p. 234)

Ursinus referred to John 2:19, 5:21 and 10:18 as well as Romans 8:11. The general correspondence with the understanding of the Early Church is noticeable in the words of Ursinus. The Early Church's understanding of salvation as restoration is conspicuous in Ursinus' words 'restored to himself a blessed, heavenly, and glorious life' (Ursinus 2012:234).

With many Scripture references, Ursinus links the resurrection of Christ for man's salvation to three main purposes (cf. Ursinus 2012:235-237):

1. For our justification - the benefits of justification gained for man through the death of Christ for our sins, could only be realised once death was conquered. There is no real victory over sin (and death caused by it) without resurrection.

2. For our regeneration - remission of sin becomes sufficient only through the new life in Christ, that is, through regeneration.

3. To secure our resurrection and glorification - Christ has risen for the preservation of our new life.
In the conclusion of question and answer 45, Ursinus refers back to its connections with the church through the centuries and across the world, and also specifically to that article of the Apostles' Creed in which the church and every member confess: 'I believe in Christ, who rose from the dead on the third day' (Ursinus 2012:241). He (Ursinus ibid) then goes on to explain the meaning of the article:

It means that I believe: (1) That Christ did truly recall his soul to his body which was dead, and quickened it. (2) That he retained a true soul and body; and that both are now glorified, and free from all infirmity. (3) That he rose by his own divine virtue and power. (4) That he rose for the purpose of making us partakers of righteousness, holiness, and glorification, which he had purchased for us. (p. 241)

\section{The Heidelberg Catechism and the Apostolic Tradition}

When it is taken into account that a substantial part of the HC is concerned with the Apostles' Creed (q \& a 22-58), and that more than 200 pages of Ursinus' commentary on the HC deals with the content and meaning of the Apostles' Creed, it is quite clear that the $\mathrm{HC}$ has its roots in the apostolic tradition. The apostolic tradition is also evident when Ursinus, for instance refers to other Early Church creeds, 'formed and received in the church': the Nicene, the Athanasian, the Ephesian, and Chalcedonian (cf. Ursinus 2012:117-118).

Ursinus explains faith in terms of an encounter with the Lord (the Word), of becoming existentially aware of being in the grip of faith and experiencing the confidence in the Lord, that the Holy Spirit ignites in our hearts (cf. Ursinus 2012:109-116). In essence (Ursinus ibid):

[F]aith cannot rely upon anything but the Word of God, as an immoveable foundation [...] God alone is true, and his word is truth $[\ldots]$ Christians must receive and believe the gospel alone [...] The sum and substance of the gospel, or of those things which are to be believed, is the Apostles' Creed. (p. 116)

Correspondence of Ursinus' understanding with that which the Early Church understood in terms of truth, the apostolic tradition and apostolic succession is strikingly obvious:

[The Creed is called apostolic] because it contains the substance of the doctrine of the Apostles [and] the Apostles delivered this sum of Christian doctrine to their disciples, and the church afterwards received it from them. It is called Catholic, because it is the one faith of all Christians. [Also] these articles constitute a certain form or rule with which the faith of all orthodox Christians should agree and conform. (Ursinus 2012:117)

The truth of the creeds of the church (Ursinus 2012):

$[D]$ oes not consist in the authority or in the decrees of men $[\ldots]$ but in [...] perpetual agreement with the holy Scriptures, and with the teachings of the whole church from the time of the Apostles, retaining and holding fast to the doctrine which they delivered, and at the same time giving testimony to posterity that they have received this doctrine from the Apostles and those that heard them. (p. 118)

The determining context that the Reformation has in the Early Church is really indispensable for our understanding of the $\mathrm{HC}$. The continuation of the same sort of understanding 
throughout the periods of the NT, the Early Church and the Reformation becomes increasingly clear to the researcher. Alister E. McGrath expressed the significance of a theological background in the Early Church when he stated that it was unlikely for a theologian of today to understand the NT better than the Christians of the 1st centuries (cf. Van de Beek 2006:248-249).

\section{The separation of literal and symbolic meaning - Creating a dualism}

Conspicuously, since the 19th century some scholars in the field of research and scientific endeavour, with spurious assertions, have been avoiding the understanding of belief and doctrine in terms of the bodily and of occurrence in the public domain. In doing so, they are indeed pursuing a direction clearly different to the statements of the NT and the Early Church. In order to reach their own hermeneutical goals, these scholars end up separating the literal and symbolic meaning of texts. For them, separation is considered necessary to render an exclusively spiritual meaning to the text. This path of an assumed exclusively spiritual meaning is followed even when so much more is evident from the texts and at risk of being lost. At risk of being bypassed is the apostolic tradition's manifestation of literal and symbolic meaning interacting and complementing one another (cf. Young 2007:xv-xvi), indeed in referring to real events and embodied deeds and words in life (cf. Thiselton 2007:50-55).

The separation of the literal and the symbolic, when emphasising a preferred outcome of spiritual meaning, has its origins in the separation of the spiritual and the bodily or material world since the days of Plato (427-347 BC). The separation of the spiritual and the bodily or material world is often referred to as the Platonist dualism. Plato had always, in some way or another, considered the human body and the material world as inferior to the world of spirit and the ideas, of which the bodily and material were merely imperfect copies. Plato (1962:126) says that 'our souls had a previous existence [...] and they possessed of intelligence'. Nature teaches the soul 'to rule and govern' and in this the soul 'resembles the divine'. Nature teaches the body 'to serve and be subject' and in this the body resembles 'the mortal part' (Plato ibid:131). Regarding the eternal future of the soul, Plato (ibid) adds:

The soul is most like that which is divine, immortal, intelligible $[\ldots]$ whereas body is most like that which is human, mortal [...] unintelligible [...] (p. 132)

But no soul which has not practiced philosophy, and is not absolutely pure when it leaves the body, may attain to the divine nature [...] (p. 135)

Every seeker after wisdom knows that up to the time when philosophy takes it over his soul is a helpless prisoner, chained hand and foot in the body, compelled to view reality not directly but only through its prison bars [...] (p. 135)

A philosopher's soul will take the view which I have described $[\ldots]$ because such a soul believes [...] that after death it reaches a place which is kindred and similar to its own nature, and there is rid for ever of human ills... the soul can have no grounds for fearing that on its separation from the body it will be blown away [...] and cease to exist altogether. (p. 137)

Platonism (in its subjective approach) always retained a very optimistic view of the capabilities of the human mind, in terms of knowledge, somehow connecting to the divine world. ' $[K]$ inship between the soul and the divine was the basis of Platonic idealism' (Young 2007:xvi).

The dualism continues in Neo-Platonism. Neo-Platonism was widely expressed on the cultural scene during the time of the NT and the Early Church - dividing the spiritual and bodily worlds, and dividing literal and symbolic meaning.

\section{Dividing the spiritual and bodily worlds, and dividing literal and symbolic meaning in Gnostic thinking}

The influence of Neo-Platonism is apparent in the views of Gnosticism. Anthony Thiselton's observation that Gnostic writings of the 2nd and 3rd centuries were even more hostile towards the bodily and the earthly is significant:

Gnostic writers held a more radical and far-reaching dualism. No gnostic could have written that the divine Word became flesh (John 1:14), nor could any have urged, 'Glorify God in your body' (1 Cor. 6:20). The gnostic texts of the second and early third centuries witness to a radical disjunction between a transcendent realm of light or spirit [...] and the realm of the bodily or material [...] The human self as an embodied being cannot be saved in gnosticism. Only the spirit can be saved by gnosis. (Thiselton 2007:51)

The Gnostics held the conviction of gnosis as a secret knowledge of the initiated, and that only the spirit could be saved by gnosis. The Gnostics were not like the Early Church, explaining their testimony in 'a narrative of occurrences in the public domain'. For the Gnostics, their gnosis took form in 'aphorisms, abstract systems, or myths', and they would therefore even explain the narratives of the Christian Gospels in wholly spiritual terms (Thiselton 2007:51).

\section{The apostolic tradition - Superseding the Platonist dualism}

The apostolic tradition was entirely different from the Gnostic view; it superseded the Platonist dualism of splitting literal and symbolic meaning - the bodily and the spiritual. Firmly grounded in the apostolic tradition, the message of the Early Church maintained the unity of body and mind and was quite the opposite of subjective philosophical speculation: in contrast to the spiritualised and docetic religious views of the Gnostics. Therefore, when the unexpected howler appears in Martin Heidegger's approval ('Nietzsche was right in saying that Christianity is Platonism for the people'; Thiselton 2007:52), Thiselton (2007:52-53) immediately, and correctly, responds: 'All the same, this is not the Christianity of the NT and of the early Fathers who guarded and transmitted apostolic tradition.' Subscribing to the philosophical views of Neo-Platonism, the Gnostics, thinking entirely subjectively, had their point of departure firmly in the human mind. In following the apostolic tradition, the faith of the early fathers 
and the Early Church found its point of departure outside of the human mind, in the reality in and surrounding the person of the Lord, Jesus Christ. Karl Barth (1886-1968) incisively describes this when he refers to the experience and response of the Early Church to the events (Ereignisse) of Christ's resurrection and ascension (Barth 2000):

It is an event which involves a definite seeing with the eyes and hearing with the ears and handling with the hands $[\ldots]$ then believing [...] and later attested by them. [...] an event within the world, in time and space. It, too, was experienced and attested, not only inwardly but outwardly, by certain men. (p. 143)

With reference to the testimony to the resurrection of Christ, Barth's words (1955:160) 'mit Augen gesehen, mit Ohren gehört, mit den Händen betastet' remind us of the exposition of Ursinus on question and answer 45 of the HC, connecting the proclaiming of the message to 'saw him, felt him, and conversed with him after his resurrection' (Ursinus 2012:233).

The apostles and their associates were the people closest to the Lord Jesus Christ, and their testimony was received by the Early Church as truth. From there onwards, the Early Church (true to the meaning of the Latin verb trado, which means to hand on) found their mission in the tradition of the apostles - the tradition of handing on the truth of the Lord Jesus Christ from generation to generation. Apostolic succession (the succession of bishops from the apostles Peter and Paul and onwards) was part of the apostolic tradition. In terms of apostolic succession, the perpetual authority and responsibility of the bishops were focused on one mission: the handing on of the truth (cf. Irenaeus 2010a:278-280).

To illustrate in the case of Irenaeus: from Irenaeus bishop of Lyons (pre-177 to pre-200) the line of succession and handing on of the truth can be traced back to Polycarp bishop of Smirna (c.69-155), and through him to the apostles (Irenaeus 2010a:280). Irenaeus (ibid) explains his connections through Polycarp, 'whom I also saw in my early youth':

But Polycarp also was not only instructed by apostles, and conversed with many who had seen Christ [...] gloriously and most nobly suffering martyrdom, departed this life, having always taught the things which he had learned from the apostles, and which the Church has handed down, and which alone are true. (p. 280)

In the mind of Irenaeus (2010a) apostolic tradition and apostolic succession had no connection with the much later claims to ecclesiastical power politics, but it was primarily concerned with the truth:

$[T]$ he apostolic tradition has been preserved continuously by those [faithful men] who exist everywhere. (p. 279)

$[A]$ nd we are in a position to reckon up those who were by the apostles instituted bishops of the Churches, and [to demonstrate] the succession of these men to our own times; those who neither taught nor knew of anything like what these [heretics] rave about. (p. 278)

$[A]$ nd by this succession, the ecclesiastical tradition from the apostles, and the preaching of the truth, have come down to us. And this is most abundant proof that there is one and the same vivifying faith, which has been preserved in the Church from the apostles until now, and handed down in truth. (p. 280)
It is therefore no surprise to read much later about handing down the truth in the Confession of Chalcedon (in 451):

[J]ust as the prophets taught from the beginning about him, and as the Lord Jesus Christ himself instructed us, and as the creed of the fathers handed it down to us. (Drobner 2007:448)

Everyday life and faith in the Early Church stood in direct opposition to the Gnostics and their views. This can be illustrated from Irenaeus' recollection of a meeting between Polycarp and Marcion, who had affinities with certain gnostic ideas (Lohse 1985:28):

And Polycarp himself replied to Marcion, who met him on one occasion, and said, 'Dost thou know me?' 'I do know thee, the first-born of Satan.' Such was the horror which the apostles and their disciples had against holding even verbal communication with any corrupters of the truth. (Irenaeus 2010a:281)

The Early Church succeeded in overcoming and rejecting the Platonist dualism by retaining the understanding of the whole human person (body and mind) and the embodied Christ, and not by separating the interaction of literal and symbolic meaning.

\section{The embodied Christ and the whole human person in the New Testament and the Early Church's understanding of restoration and salvation}

The NT and the Early Church fathers see and understand man in the unity of body and mind. Anthony Thiselton (2007) points out that the NT portrays both the words and the deeds of Christ as related to a physical and human body:

The New Testament [...] at times prefers to focus on Christ as the 'place' of meeting rather than on an earthly place as such. Even so, Christ enters the scene as the 'enfleshed Word' (John 1:14), and as the embodied Christ. His 'flesh' is the entire embodied medium of his deeds and words in life (Heb. 5:7). (p. 55)

The NT, however, does not give any detail on the mystery of the resurrected body and glorification. In referring to the apostle Paul's arguments in 1 Corinthians 15, John Macquarrie (2003) mentions:

Paul's arguments, make it clear that what is resurrected is not the dead body that has been laid in the grave [...] So resurrection cannot be anything so simple as the resuscitation of a corpse [...] It would be quite different from the resurrection of Jesus Christ, who the New Testament claims, has conquered death and is alive for ever. To go back to Paul's argument, a natural body of flesh and blood could not be the bearer of a death-transcending existence. (p. 408)

Jürgen Moltmann (2010) emphasises the whole man in the bodily resurrection:

Ideas about a resurrection from the dead presuppose death, and what is being thought of is quite clearly a bodily resurrection. Instead of 'raising' Paul can also say zoopoiesis, meaning the giving life to mortal bodies through the spirit of life which 'dwells' in them (Rom. 8:11). Paul also shows awareness of the special nature of the woman's body, with its ability to give birth, when he writes: 'The whole creation has been groaning 
in travail till now' (Rom. 8:22). In 1 Cor. 15 he calls the same process 'changing', transformation, and in Phil 3:21 he looks to the 'glorious (transfigured) body of Christ'. If we take the word zoopoiesis, we mean the lived life; transformation presupposes life as 'minted form which takes shape as it lives', as Goethe wrote. Transfiguration, finally, anticipates the transmutation into the beauty of the divine life. According to all these ideas, what comes into being after death in the place of mortal life is not a different life. It is this mortal, this lived, and this loved life which will be raised, healed, reconciled, completed, and thus find its divine destiny. (pp. 61-62)

Robert H. Gundry (1994) rejects the view that the NT 'presents conflicting versions of Jesus' resurrection' - one being a bodily version and the other a spiritual version:

My position is threefold: (1) the NT presents a unified view of the nature of Jesus' resurrection; (2) according to that view, he rose from the dead in a physical body; and (3) the physicality of that body forms an essential element of his risen being. (p. 206)

Wolfhart Pannenberg (1976) states quite clearly that resurrection does not imply a disembodied spirituality:

Paul made it unequivocally clear that for him 'resurrection from the dead' did not mean the return to earthly life, but a transformation into the new life of a new body. In 1 Cor. 15:35-56 Paul expressly deals with the question how we ought to think of the physical reality of the person raised from the dead. Here it counts for him as being a settled thing that the future body will be a different body from the present one; it will not be a physical body but - as Paul expresses it - a 'spiritual body' (1 Cor. 15:43f.). What he means by this is not a disembodied spirituality, in the sense of some Platonic tradition or other ... Paul describes the relation of the immortal, spiritual body to the present mortal, physical body as a radical transformation [...] On the other hand, however, it is this present earthly body which will experience the transformation; so that the transformation stands in a relationship to our present existence. What is to be created in place of the present body is not something totally different from it.

What Paul has to say here does not apply in the first place to the resurrection of Jesus especially; his subject is the resurrection which Christians have to expect. For Paul, however, the two belong together. In his view, the resurrection of Jesus justifies Christians in hoping for their own resurrection. It is of the greatest importance for him that Christians should participate in that particular reality which has already appeared in Christ. (pp. 98-99)

An important document of the World Council of Churches (1996) stresses the reality of the risen Christ and the future new humanity:

The mystery of the resurrection has always provoked different interpretations. These should, however, not divide Christians as long as they together confess the reality of the resurrected Jesus $[\ldots]$ The life that is based on the resurrection of Jesus seeks [...] the renewal of the whole human community since it knows that Jesus rose again to be the head and Lord of the new humanity. (pp. 67-68)

From the consensus of the ecumenical world, it is clear that there is really no way of getting away from the determining context of 'the language of the fathers and the councils of the early church' (Agreed Statement on Christology 2000:289). From generation to generation, the apostolic tradition has been carrying its message of man's salvation and the restoration of creation, as understood on the basis of God's acts in the real events of the cross and resurrection of Jesus Christ, the Lord.

Furthermore, this message knows and accepts no argument for diminishing the status and importance of the unity of the full divinity and the full humanity in the one person of Christ - in order to favour an independent portrayal of a new human existence according to man's own design. To discard the ecumenical consensus of the Early Church would, in effect, mean discontinuing being part of the Christian Church (cf. Macquarrie 2003:383).

On the ecumenical front in 1991, through the initiative of the World Alliance of Reformed Churches (WARC), five Oriental Orthodox churches (Coptic, Syrian, Armenian, Ethiopian and Malankara [Indian]) showed their openness to enter into a bilateral dialogue. The highlights of this dialogue to date have been the 1994 Agreed Statement on Christology and the 1998 Draft Common Statement, summarising the elements of the discussion to that date (Agreed Statement on Christology 2000:291). Merely a few sentences from the Agreed Statement on the Christology (ibid) already underline the relevance for our study:

[The] incarnate Son is the manifestation of the Holy Trinity in the sphere of earthly human history [...] God assumes the human condition and nature in all their aspects and dimensions. All this takes place for us human beings and for our salvation [The] Son [...] became fully human in body and soul so that through it he might unite himself with the entire creation. (pp. 288-289)

Furthermore, in referring to the full divinity and full humanity of Christ (Agreed Statement on Christology 2000):

What can be said is that through the perchoresis or interpenetration of the two natures in the unity of Christ's person the human nature is restored, sustained and glorified as the new and perfect humanity of the last Adam [...] (p. 289)

Frances Young points out that, in identifying the link between man's salvation and God's creation and recreation in Christ, recent scholarship in Early Church and Patristic studies persistently affirmed the physical character of the resurrection (Young 2007:xv). Reading the work of the early Church Fathers confirms this. Irenaeus (pre-177 to pre-200) understands man's salvation in terms of restoration and recreation, and obviously refers to 'salvation of the complete man, that is, of the soul and body' (Irenaeus 2010b:606-607). In explaining man's salvation, Origenes (c.185-254) refers to the whole human person of Christ, but without losing sight of both the humanity and the divinity in the one person of Christ: "The humanity of the Word, of "the immortal God", involves "a mortal body and a human soul", whilst still remaining "essentially the Word"' (Origenes 2007:503).

When referring to God's intervention in Christ for the sake of man's salvation, Tertullian (c.160-c.220) emphasises the whole person of man (Tertullian 2007):

[T] he restoration of flesh and blood, in order the more emphatically to express the resurrection of such bodies as have even been devoured [...] Since, however, things which belong to the soul 
have nothing allegorical in them, neither therefore have those which belong to the body. For man is as much body as he is soul [...] (p. 568)

[T]hings which are destined for the body should be carefully understood in a bodily sense, - not in a spiritual sense [The] bodily character of the flesh is indicated by our Lord whenever $\mathrm{He}$ mentions the resurrection, at the same time without disparagement to the corporeal nature of the soul [...] (p. 569)

For Tertullian (cf. 2007:584-588), the entire person of the resurrected Christ, at the right hand of God in heaven, is the guarantee for the resurrection of our flesh:

[I]n Christ you have acquired both heaven and the kingdom of God; Jesus is still sitting there at the right hand of the Father, man, yet God - the last Adam, yet the primary Word - flesh and blood, yet purer than ours - who 'shall descend in like manner as He ascended into heaven' the same both in substance and in form. (p. 584)

For the Early Church fathers, indeed significantly, man's salvation is necessarily expressed in terms of a bodily resurrection and the restoration of the entire human person, and then specifically related to the cross and resurrection of the embodied Christ. In the Early Church's understanding, 'some inherent immortality of the soul as the Platonists assumed' is pure conjecture (cf. Young 2007:85). Frances Young (2010) elaborates:

It is important to emphasise the physicality of the Church's teaching. In the face of heretics who turned resurrection into immortality of the soul, the Church linked it with creation out of nothing. If God can create once, he can create again, and what it is all about is the restoration of what we might call full-bodied life [...] Christ's resurrection was the first-fruits which confirmed the message for those who became his disciples, and prepared themselves for his coming kingdom. (p. 57)

\section{Conclusion}

The contexts of the NT, the Early Church and the Reformation, impacting on the faith and meaning finally expressed in the text of the HC and manifesting a united horizon of understanding with the text of the Catechism, clearly and solely allow for an interpretation based upon a point of departure in the objective reality of the bodily resurrection of Christ, signifying proleptically man's future salvation. The bodily resurrection reflected in this fusion of understanding in effect means understanding man in terms of the unity of body and mind. In answer 45, the HC explained man's redemption, salvation, new life and especially man's future on the basis of Christ's resurrection. Even today, theologians of reformed orientation can indeed build upon the sound theological basis of the HC. Understood in conjunction with Wolfhart Pannenberg's concept of prolepsis, the resurrection of Jesus Christ is representing and actualising man's future in an event that has already happened, i.e. realising something of the future in the present. Pannenberg stresses the significance of the event of the resurrection of Jesus Christ in terms of its unity with the future and, indeed, as a proleptic understanding of the future: ' $[W]$ ith Jesus the end is not only [...] seen in advance, but it has happened in advance' (Pannenberg 1973:61; cf. pp. 108-114, 157, 185, 186).
Merely offering a spiritual or symbolic expression, without the background of a real event, as interpretation for question and answer 45, does not correspond with the original intention of the $\mathrm{HC}$, as written and explained by Ursinus in his commentary. Both the HC and the commentary of Ursinus were based on the ecumenical understanding of Ursinus' time, and were surely intended as an understanding true to the NT and the Early Church. When the hermeneutical understanding of the $\mathrm{HC}$ originates from the actual event of the resurrection of Jesus Christ, clearly following the understanding of the NT and the apostolic tradition, God's revelation in Christ comes to the fore - meaning that God in his encounter with man is in control. When taking revelation into account, it is avoided that God could be considered the product of the human mind.

When the testimony of the real and impacting environment of the NT and the Early Church becomes hidden behind the contemporary convictions and perceptions of the autonomous human mind, then the original message of salvation and hope simply fades away.

\section{Acknowledgements Competing interests}

The author declares that he has no financial or personal relationship(s) that may have inappropriately influenced him in writing this article.

\section{References}

Agreed Statement on Christology, 2000, 'A statement of the Reformed-Orthodox dialogue, Limassol, Cyprus 1994', in J. Gros, H. Meyer \& W.G. Rusch (eds.) Growth in Agreement II - Reports and agreed statements of ecumenical conversations on a world level: 1982-1998, WCC/Eerdmans, Geneva/Grand Rapids.

Augsburg Confession, 2005, 'Which was submitted to His Imperial Majesty Charles V at the Imperial meeting of Augsburg in the year 1530', in P.T. McCain, R.C. Baker, G.E. Veith \& E.A. Engelbrecht, CONCORDIA -The Lutheran confessions (A reader's edition of the book of Concord), transl. W. Hermann, T. Dau \& G.F. Bente, pp. 45-89, Concordia Publishing House, Saint Louis.

Barth, K., 1955, Die Kirchliche Dogmatik IV, 2 - Die Lehre von der Versöhnung, Evangelischer Verlag, Zürich.

Barth, K., 1964, The Heidelberg Catechism for today, transl. S.C. Guthrie, Epworth Press, London.

Barth, K., 1972, Protestant theology in the nineteenth century, transl. B. Cozens \& J. Bowden, SCM Press, London. PMCid:PMC1786127

Barth, K., 2000, Church Dogmatics IV, 2 - The doctrine of reconciliation, transl. G.W. Bromiley, T\&T Clark, Edinburgh.

Bierma, L.D., 2005a, 'The purpose and the authorship of the Heidelberg Catechism', in L.D. Bierma (ed.), An introduction to the Heidelberg Catechism - Sources, history and theology, pp. 49-74, Baker Academic, Grand Rapids.

Bierma, L.D., 2005b, 'The sources and the theological orientation of the Heidelberg Catechism', in L.D. Bierma (ed.), An introduction to the Heidelberg Catechism Sources, history and theology, pp. 75-102, Baker Academic, Grand Rapids.

Bierma, L.D. (ed.), 2005c, An introduction to the Heidelberg Catechism - Sources, history and theology, Baker Academic, Grand Rapids.

Bultmann, R., 1989, New Testament and mythology - and other basic writings, transl. S.M Ogden, Fortress Press, Philadelphia.

Bultmann, R., 1993, Theology of the New Testament, vol. 1, transl. K. Grobel, SCM Press, London.

Busch, E., 2010, Drawn to freedom - Christian faith today in conversation with the Heidelberg Catechism, transl. W.H. Rader, Eerdmans, Grand Rapids.

Calvyn, J., 1981, Calvyn se Kategismus, transl. H.W. Simpson, Potchefstroomse Teologiese Publikasies, Potchefstroom.

DeYoung, K.L., 2010, The good news we almost forgot - Rediscovering the gospel in a 16 th century Catechism, Moody Publishers, Chicago.

Drobner, H.R., 2007, The fathers of the church - A comprehensive introduction, transl. S.S. Schatzmann, Hendrickson Publishers, Massachusetts.

Gadamer, H-G., 2006, Truth and method, transl. J. Weinsheimer \& D.G. Marshall, Continuum, London. 
Gundry, R.H., 1994, 'The essential physicality of Jesus' resurrection according to the New Testament', in J.B. Green \& M. Turner (eds.), Jesus of Nazareth: Lord and New Testament', in .B. Green \& M. Turner (eds.), Jesus of Nazareth: Lord and
Christ. Essays on the historical Jesus and New Testament Christology, pp. 204-219, Christ. Essays on the historico
Eerdmans, Grand Rapids.

Irenaeus, 2010a, 'Against Heresies (Book III), in A. Roberts, J. Donaldson \& A. Cleveland Coxe (eds.), Saint Irenaeus of Lyons - Against Heresies, pp. 275-391, Ex Fontibus, USA

Irenaeus, 2010b, 'Against Heresies (Book V)', in A. Roberts, J. Donaldson \& A. Cleveland Coxe (eds.), Saint Irenaeus of Lyons - Against Heresies, pp. 553-655, Ex Fontibus, USA

Kähler, M., 1964, The so-called historical Jesus and the historic, biblical Christ, transl. C.E. Braaten, Fortress Press, Philadelphia.

Kant, I., 1974, Critique of pure reason, transl. J.M.D. Meiklejohn, J.M. Dent \& Sons Ltd., London.

Klein, W.W., Blomberg, C.L. \& Hubbard, R.L., 1993, Introduction to Biblical interpretation, Word Publishing, Dallas/London/Vancouver/Melbourne.

Lohse, B., 1985, A short history of Christian doctrine, transl. F.E. Stoeffler, Fortress Press, Philadelphia.

Luther, M., 2005a, 'Small Catechism', in P.T. McCain, R.C. Baker, G.E. Veith \& E.A Engelbrecht (eds.), CONCORDIA - The Lutheran confessions (A reader's edition of the book of Concord), transl. W. Hermann, T. Dau \& G.F. Bente, pp. 333-374, Concordia Publishing House, Saint Louis.

Luther, M., 2005b, 'Large Catechism', in P.T. McCain, R.C. Baker, G.E. Veith \& E.A Engelbrecht (eds.), CONCORDIA -The Lutheran confessions (A reader's edition of the book of Concord), transl. W. Hermann, T. Dau \& G.F. Bente, pp. 375-470, Concordia Publishing House, Saint Louis.

Macquarrie, J., 2003, Jesus Christ in modern thought, SCM Press, London.

Maley, W.T., 2011, 10 ways of thinking about deconstruction, viewed 02 November 2011, from http://www.alansondheim.org/old/DECON

Moltmann, J., 2000, Experiences in theology: Ways and forms of Christian Theology, transl. M. Kohl, Fortress Press, Minneapolis.

Moltmann, J., 2010, Sun of righteousness, arise! - God's future for humanity and the earth, transl. M. Kohl, Fortress Press, Minneapolis.
Origenes, 2007, 'Against Celsus', in A. Roberts, J. Donaldson \& A. Cleveland Coxe (eds.) The Ante-Nicene Fathers, vol. 4., pp. 395-669, Cosimo Classics, New York.

Palmer, R.E., 1969, Hermeneutics - Interpretation theory in Schleiermacher, Dilthey, Heidegger, and Gadamer, Northwestern University Press, Evanston

Pannenberg, W., 1973, Jesus - God and Man, transl. L.L. Wilkins \& D.A. Priebe, SCM Press, London.

Pannenberg, W., 1976, The Apostles' Creed - In the light of today's questions, transl. M. Kohl, SCM Press, London.

Plato, 1962, 'Phaedo', in The last days of Socrates, pp. 99-183, transl. \& introd. H. Tredennick, Penguin Books, London.

Ricoeur, P., 2009, Hermeneutics and the human sciences, transl. J.B. Thompson (ed.), Cambridge University Press, Cambridge.

Tertullian, 2007, 'On the resurrection of the flesh', in A. Roberts, J. Donaldson \& A Cleveland Coxe (eds.), The Ante-Nicene Fathers, vol. 3, pp. 545-596, Cosimo Classics, New York.

Thiselton, A.C., 2007, The hermeneutics of doctrine, Eerdmans, Cambridge. PMCid: PMC2441648

Ursinus, Z., 2005a, 'The smaller Catechism', transl. F. Klooster, J. Medendorp \& L.D. Bierma, in L.D. Bierma (ed.), An introduction to the Heidelberg Catechism - Sources, history and theology, pp. 135-162, Baker Academic, Grand Rapids, MI.

Ursinus, Z., 2005b, 'The larger Catechism' transl. F. Klooster, J. Medendorp \& L.D. Bierma, in L.D. Bierma (ed.), An introduction to the Heidelberg Catechism - Sources, history and theology, pp. 163-223, Baker Academic, Grand Rapids, MI.

Ursinus, Z., 2012, The commentary of Zacharias Ursinus on the Heidelberg Catechism, transl. G.W. Williard, Hardpress, Miami/Florida.

Van de Beek, A., 2006, Van Kant tot Kuitert-De belangrijkste theologen uit de 19 e en 20e eeuw, Uitgeverij Kok, Kampen.

World Council of Churches, 1996, 'Faith and order paper no. 153', in Confessing the one faith - An ecumenical explication of the Apostolic faith as it is confessed in the Nicene-Constantinopolitan creed 381, WCC Publications, Geneva.

Young, F.M., 2007, The making of the creeds, SCM Press, London.

Young, F.M., 2010, Holiness and mission - Learning from the Early church about mission in the city, SCM Press, London. 